\title{
Effects of moderate levels of oxidized fat in animal diets under controlled conditions
}

\author{
By K. J. Carpenter and J. L. L'Estrange, School of Agriculture, University of \\ Cambridge and C. H. LEA, Low Temperature Research Station, Cambridge
}

All practical pig and poultry diets contain some fat, usually in the region of 2-5\%, derived from their ordinary constituents-grains, oilseed meals, animal protein concentrates and so on. In addition up to $5 \%$ may be added in the form of an animal fat, usually a tallow. By the time the mixed feed is eaten, perhaps months after preparation of its constituents, the unsaturated fatty acids of all this fat have normally undergone some degree of oxidation.

It is therefore of concern to both the producer and user of feeding-stuffs to know whether such oxidized fat can be harmful to stock and, if so, what measures of quality control should be used to avoid the danger.

There has never been any official recommendation on the point in this country but some commercial laboratories have, in recentyears, been determining the peroxide value of the extractable lipid in feeding-stuffs and reporting that a sample was 'unsuitable for young stock and only to be used at low levels for older stock' when the value was in excess of $20 \mu$ equiv. peroxide oxygen/g lipid or even, for tallow, when the value exceeded $2 \mu$ equiv./g. On the alternative scale, which will be used in the remainder of this paper, these two values are halved and become Io and I $\mu$ moles/g respectively.

The origin of these two standards is obscure. The first may go back to a comment of Gray \& Robinson (I94I) in a footnote to a table giving analytical data for a series of meat meal samples: 'a fat with a peroxide value of more than 20 is definitely rancid', though their final conclusion is that such 'rancid' meat meals may be used without harm. A value of this magnitude has also been used in the stability testing of lard. The second figure, a peroxide value of less than 2 for tallow, may originate from specifications laid down for fats for human consumption.

With either, the original context of such standards appears to be that they represented levels of oxidation thought to be accompanied for man by detectable changes in flavour. Justification for the use of peroxide values in animal feeding-stuffs would have to be ( $\mathrm{r}$ ) that peroxides are toxic or appetite-depressant per se or (2) that the values give an indirect indication of more complex changes resulting in deterioration in the nutritive value or palatability of the feeding-stuff. Certainly it has been the opinion of many practical people that poor results with farm stock can at times be related to some real, though necessarily ill-defined, 'staleness' of the food.

We have been attempting in a series of experiments to reproduce such poor results under controlled conditions by using materials and diets containing oxidized fats under conditions we judged to be as unfavourable as any that might occur in practice if normal compounding procedures were followed, except that no quality control or other checks were imposed on the state of oxidation of the dietary fat.

Our first experiments were with tallow oxidized to a peroxide value of approximately $100 \mu$ moles $/ g$. The rancid tallow was used in the normal way, i.e. premixed 
with $0.02 \%$ BHT (2,6-di-t-butyl-4-methyl-phenol) and added at a level of $5 \%$ to a practical broiler diet which was then given to weanling rats, both while fresh and again after several weeks' storage (Lea, Parr, L'Estrange \& Carpenter, 1964). Control rats received a similar diet made up with fresh tallow of peroxide value nil. The whole experiment was repeated with chicks (L'Estrange, Carpenter, Lea \& Parr, I965a). In both experiments the animals receiving the diet made up from the high-peroxide tallow remained apparently as healthy as the controls on the diet made up from fresh tallow, and their growth rate was not significantly different (Table $\mathbf{r}$ ).

Table I. Mean performance of young rats and chicks on a complete diet made up with $5 \%$ oxidized tallow, as a percentage of that on a similar diet with fresh tallow, and judged by three criteria*

\begin{tabular}{|c|c|c|c|}
\hline \multirow{3}{*}{$\begin{array}{l}\text { Rats from weaning to } 6 \text { weeks old: } \\
\text { With diet made up when experiment began }\end{array}$} & Feed eaten & Weight gain & $\begin{array}{l}\text { Vitamin A } \\
\text { (i.u./liver) }\end{array}$ \\
\hline & & & \\
\hline & 95 & 97 & $53 \dagger$ \\
\hline $\begin{array}{l}\text { With diet stored } 7 \text { weeks at } 20^{\circ} \text { before } \\
\text { experiment began }\end{array}$ & 102 & IOI & $72 t$ \\
\hline $\begin{array}{l}\text { Chicks from hatching to } 8 \text { weeks old } \\
\text { (dict made up when experiment began) }\end{array}$ & 108 & 106 & $64 t$ \\
\hline
\end{tabular}

*Summarized from Lea, Parr, L'Estrange \& Carpenter (1964); L'Estrange, Carpenter, Lea \& Parr $(1965 a)$. The oxidized tallow had an initial peroxide value of approximately $100 \mu \mathrm{moles} / \mathrm{g}$, but the peroxide value of the total dietary lipids fell progressively during storage and reached approximately $30 \%$ of the initial value after 6 weeks.

tSignificantly different from the corresponding control values.

It must be noted, first, that our diet contained vitamins $A, D$ and $E$ in stabilized form (though only at the ordinary recommended levels) and BHT, but that this was done to follow commercial practice and, second, that the peroxide value of the added oxidized fat fell drastically during storage of the mixed diet.

Our next experiment was carried out with a more highly unsaturated fat, in case the oxidation products derived from it would prove to be more harmful than those from tallow. Turkeys were used because it has been suggested that this is a particularly sensitive species. Anchovy oil, with an initial iodine value of r9o was allowed to oxidize in a premix with white fish meal to a peroxide value of 60-100. Part of it was then stored at $-20^{\circ}$ and mixed into the diet of young turkeys every day. For another treatment, the diet with the oxidized oil already added to it was stored for 3 months at $15{ }^{\circ}$ in contact with air before feeding began, to allow ample opportunity for interaction of the oxidized fat with other oxidizable nutrients. No antioxidant was used in these diets.

The turkeys on both treatments with oxidized fish oil had a mean live-weight gain over 6 weeks that was $94 \%$ of that of controls receiving fresh tallow and $96 \%$ of that of birds receiving fresh anchovy oil (non-significant differences), and all appeared equally healthy (L'Estrange, Carpenter, Lea \& Parr, r $965 b$ ). The amount of fish oil included was only $\mathrm{I} \cdot 5 \%$, but this level is already higher than could be used in a practical turkey diet since it imparts a definite fishy flavour to the roasted meat. 
Lastly, a trial has been carried out with young pigs, a species in which deaths and upsets have been widely attributed to rancidity of the diet. We chose as source of oxidized fat a commercial sample of meat meal of high fat content $(17 \%)$ that had already been rejected by a commercial analyst as 'unfit for feeding' because its fat had the very high peroxide value of approximately 100. The meal was included as $10 \%$ of a practical-type diet for early-weaned piglets. Since even the freshly manufactured samples of meat meal we examined all had significant peroxide values, we prepared a control material from a solvent-extracted meal with the addition of fresh lard. The results (unpublished) are summarized in Table 2. Again, there was only a small (non-significant) difference in growth and no apparent difference in health of animals on the different treatments.

Table 2. Mean performance of eighteen pigs fed from 5 to 16 weeks of age on a diet containing $10 \%$ of either fresh or high-peroxide meat meal

$\begin{array}{lcccc} & \begin{array}{c}\text { Fresh meat } \\ \text { meal }\end{array} & \begin{array}{c}\text { High-peroxide } \\ \text { meat meal* }\end{array} & \begin{array}{c}\text { High-peroxide } \\ \text { meat meal } \\ \text { +vitamin E }\end{array} & \text { SE† } \\ \text { Losses } & 2 & 2 & 2 & \pm 2 \cdot \mathrm{I} \\ \text { Live-wt gain (lb/head) } & 89 & 84 & 91 & \pm 0.02 \\ \text { Feed conversion (lb/lb wt gain) } & 2 \cdot 55 & 2 \cdot 57 & 2 \cdot 53 & \pm 2 \cdot 3 \\ \left.\text { Vitamin A in liver (i.u. } \times 10^{-3}\right) & 29 & 27 & 99 & \pm 8 \cdot 1 \\ \text { Serum aspartate aminotransferaset } & 88 & 108 & 9 / 16 & \pm 2\end{array}$

*The meat meal contained ${ }_{1} 7 \%$ fat of peroxide value I05, and contributed $\mathrm{I} \cdot 8 \mu$ moles peroxide $/ \mathrm{g}$ freshly mixed diet. A second batch was mixed after 7 weeks when the peroxide value of the first had fallen to about half its initial value.

+None of the differences between treatment means was statistically significant.

IValues, in Sigma-Frankel units (Sigma, 1964), for the concentration of aspartate aminotransferase of serum taken at slaughter.

Our investigations are still in progress, but so far, in feeding trials with four species of animal and a variety of feeds that seem to cover the most extreme conditions under which oxidized fat might be present in practical pig and poultry diets, there has been no evidence of significant harm having been caused. This is despite confident predictions from people with field experience that we had chosen conditions that should result in serious toxic effects.

Are our results, in fact, in conflict with those of controlled experiments reported by others? Some of these, in which fats of known peroxide content have been added to balanced diets for rats or chicks, are summarized in Tables 3 and 4 . In short, it appears that growth depression from oxidized oil has only resulted when there have been at least $40 \mu$ moles peroxide/g diet. In all the tests in which the diet has contained $10 \mu$ moles or less there has been no evidence of harm. Crampton, Common, Farmer, Wells \& Crawford (I953) drew a somewhat similar conclusion from their own unpublished observations.

Peroxides are, of course much more toxic when given by injection, as explained earlier in the Symposium by O'Brien \& Frazer (1966). The lower toxicity when they 25 (1) 3 
Table 3. Effect on growth of adding oxidized fat to the complete diet of young rats receiving adequate vitamin $E$, as reported by various authors

\begin{tabular}{|c|c|c|c|}
\hline Reference & Oxidized fat in diet & $\begin{array}{l}\text { Peroxide in diet } \\
(\mu \text { moles } / g)\end{array}$ & $\begin{array}{c}\text { Growth } \\
\text { depression } \\
\text { as compared } \\
\text { with controls* }\end{array}$ \\
\hline Greenberg \& Frazer (1953) & $10 \%$ soya oil of peroxide value & 54 & $22 \%$ \\
\hline Kaunitz, Johnson \& Slanetz (1952) & $\begin{array}{l}540 \\
\text { I0\% lard of peroxide value } \\
200-300\end{array}$ & $20-30$ & Very slight \\
\hline Andrews, Mead \& Griffith (1960) & $\begin{array}{l}1 \cdot 7-20 \% \text { soya oil of peroxide } \\
\text { value } 600\end{array}$ & $\begin{array}{r}10 \\
40 \\
80 \\
120\end{array}$ & $\begin{array}{c}\text { None } \\
30 \% \\
\text { Complete } \\
\text { Rats killed }\end{array}$ \\
\hline Kreier, Elwood \& Norton ( I96I) & $\begin{array}{l}20 \% \text { tallow of peroxide value } \\
258\end{array}$ & 52 & $18 \%$ \\
\hline $\begin{array}{l}\text { Lea, Parr, L'Estrange \& Carpenter } \\
\text { (I964) }\end{array}$ & $\begin{array}{l}5 \% \text { tallow of peroxide value } 93 \\
\text { (falling in mixed diet) }\end{array}$ & $\begin{array}{l}4.6 \text { (falling } \\
\text { with storage) }\end{array}$ & None \\
\hline
\end{tabular}

*All experiments werc for 6-10 wecks.

are given orally is presumably due to their reactivity which results in their being largely reduced during the absorption of oxidized fat.

Since it seems almost impossible to construct a practical diet for pigs and poultry containing more than $5 \mu$ moles peroxide/g diet, toxicity per se of peroxide is probably not a problem for the feed compounder. Further, if calculations of permissible peroxide levels are to be made, it would seem more reasonable to base them on the total diet, as has been done above, rather than on the extractable lipids. Thus a peroxide value of $\mathrm{I} 5^{\circ} \mu \mathrm{moles} / \mathrm{g}$ lipid may seem high for a meat meal but, if the meal contains only $5 \%$ fat and is included in a diet at a level of not more than $10 \%$, it can contribute no more than $0.75 \mu$ moles peroxide $/ g$ diet.

Both Greenberg \& Frazer (1953) and Kaunitz (I962) emphasize that, when mild growth depression is observed with rats, the effect of the oxidized fat may be largely through palatability. With prolonged feeding, animals may become adapted and recover their appetite and then show an almost normal growth rate. It is possible that this factor was operating in a pig experiment (Oldfield, Sinnhuber \& Rasheed, I963) in which $10 \%$ of oxidized menhaden fish oil (not, of course, a practical level) added to a diet supplemented with tocopheryl acetate, caused a fall in appetite, but the same weight gain/lb food eaten as for the controls. There appear to be no more serious effects over the long period than are revealed in shorter experiments. Kaunitz, Johnson \& Slanetz (1952) were able to rear five generations of rats on a diet containing $10 \%$ of rancid lard.

\section{Oxidation beyond the 'peroxide' stage}

With fish meal in particular, high peroxide values do not indicate 'staleness' of the material because peak peroxide values typically occur as early as from 3 days to 3 weeks after manufacture, and then decline, although the material continues to absorb oxygen and its lipid to decrease in iodine value. 
Table 4. Effect on growth of adding oxidixed fat to the complete diets of young chicks and pigs receiving adequate vitamin $E$ as reported by various authors

\begin{tabular}{|c|c|c|c|}
\hline eference & Oxidized fat in diet & $\begin{array}{l}\text { Peroxide in diet } \\
\quad(\mu \text { moles } / \mathrm{g})\end{array}$ & $\begin{array}{l}\text { Growth } \\
\text { depression } \\
\text { as compare } \\
\text { with contro }\end{array}$ \\
\hline \& Robinson (I94I) & $\begin{array}{l}\mathbf{1} \cdot 3 \% \text { from meat meal of } \\
\text { peroxide value } 50\end{array}$ & 0.64 & None \\
\hline $\begin{array}{l}\text { ch, Biely, Claggett \& Tarr } \\
962)\end{array}$ & $\begin{array}{l}1.5 \% \text { lard of peroxide value } 50 \\
\text { 10\% oil extracted from herring } \\
\text { meal }\end{array}$ & 0.75 & $\begin{array}{l}\text { None } \\
\text { None }\end{array}$ \\
\hline enter, Lea \& Parr $(1963)$ & $\begin{array}{l}3 \cdot I \% \text { herring oil of peroxide } \\
\text { value } I 42\end{array}$ & $4 \cdot 3$ & None \\
\hline $\begin{array}{l}\text { strange, Carpenter, Lea \& Parr } \\
\left.96_{5} a\right)\end{array}$ & $\begin{array}{l}5 \% \text { tallow of peroxide value } 7 \mathbf{I} \\
\text { (declining with storage of diet) }\end{array}$ & $\begin{array}{c}3.6 \\
\text { (then declining) }\end{array}$ & None \\
\hline $\begin{array}{l}\text { field, Sinnhuber \& Rasheed } \\
\text { I963) }\end{array}$ & $\begin{array}{l}\text { I0\% menhaden oil of } \\
\text { peroxide value } 61\end{array}$ & $6 \cdot I$ & None $\uparrow$ \\
\hline $\begin{array}{l}\text { strange, Carpenter, Lea \& Parr } \\
\text { unpublished) }\end{array}$ & $\begin{array}{l}\mathrm{I} \cdot 7 \% \text { from meat meal of } \\
\text { peroxide value } 105 \\
\text { (declining with storage of diet) }\end{array}$ & $\begin{array}{c}\mathrm{I} \cdot 8 \\
\text { (then declining) }\end{array}$ & Nonet \\
\hline
\end{tabular}

\footnotetext{
*The peroxide value of the oils was not reported, but the oils were extracted from herring meals after 2-10 months of storage in air.

In these experiments the growth on an oxidized-fat diet including supplementary tocopheryl acetate has been compared with that on the only 'control' diet, i.e. with the same fat in fresh condition, which contained no such supplement.
}

There have been a few studies of oils oxidized well past the 'peroxide' peaks. Laksesvela (I96I) and March, Biely, Claggett \& Tarr (I962) both added 10\% of lipids, extracted from herring meal that had been allowed to oxidize for many months, to balanced chick diets and found no deleterious effect. Kaunitz et al. (1952) found that lard oxidized for ten times the period required to reach the peak peroxide value produced only the same slight (and non-significant) growth depression that had been obtained with material at its peak peroxide value. It seems reasonable to suppose that the lower toxicity of very severely oxidized and polymerized fats is partly due to reduced digestibility and absorption (cf. Degkwitz \& Lang, I 962).

\section{Induction of vitamin deficiencies}

So far only investigations of the minimum levels of oxidized fats required to give trouble with diets containing fully adequate vitamin supplements have been considered. There is considerable evidence that much lower levels of oxidized fat will hasten or exacerbate deficiency states when added to diets low in any of a number of vitamins. Kaunitz (1962) has reviewed some of these effects in rats with both the water-soluble and fat-soluble vitamins, and chicks show similar effects (March et al. 1962). Vitamin A is particularly susceptible to oxidation when in contact with oxidizing fat, as will be discussed by Clement ( 1966 ), later in the Symposium. Loss can be largely avoided by the use of 'stabilized' vitamins. Even so, in three experiments (Table I) the animals receiving oxidized fat stored significantly less vitamin A in their 
livers than the controls, but since this storage was achieved on diets providing only just adequate supplies of this vitamin the adverse effect is not considered serious.

The nature and level of the fat in diets is particularly critical in influencing the requirement for vitamin $\mathrm{E}$, and most of the troubles associated with the use of unsaturated and autoxidized fats in animal feeding appear to have been induced vitamin $\mathrm{E}$ deficiencies.

Fat does not have to be oxidized for such an effect to result. With calves, muscular dystrophy has been produced by adding fresh, highly unsaturated oil to a milk substitute low in vitamin E just before feeding (Blaxter, Wood \& McDonald, I953). With chicks it is suggested that tocopherol requirement is finally determined by the level of linoleic acid in their tissues (Machlin \& Gordon, I960) and it is well established that vitamin $\mathrm{E}$ requirement increases with the polyunsaturated fatty acid content of the diet.

However, vitamin $\mathbf{E}$ is an important antioxidant in grains and other feeding-stuffs, as well as being active in animal's tissues in vivo. It is destroyed by a coupled oxidation reaction in the presence of autoxidizing fat and oxidation of the fat in a diet increases the tendency to vitamin E deficiency. If, however, oxidation is so severe that most of the polyunsaturated fatty acid is destroyed, then the fat loses its antivitamin E activity, as shown by Dam (r943) for fish oil oxidized until its iodine value had been reduced by two-thirds.

In Scandinavian work in which pig diseases were associated with the autoxidation of dietary fat (cf. reviews by Swahn \& Thafvelin, I 962; Grant I 966) it was reported that the ground grain used showed very rapid oxidation of the fat during storage, as indicated by rising peroxide values. Such a condition may perhaps be associated with wet conditions at harvest time.

Grain as used in Britain seems, on the contrary, to have predominantly stabilizing antioxidant properties rather than pro-oxidant ones. Our experience has been that adding oxidizing fat to ordinary pig and poultry diets based on barley or on a mixture of grains results in a rapid decrease in peroxide value, and little further oxidation. This difference may explain why Dow, Lawson, McFerran \& Todd (1963) found no losses in pigs when feeding with oxidized oil in a way that had precipitated a vitamin $\mathrm{E}$ deficiency condition in Scandinavia.

Changes to intensive, high-energy diets for poultry including breeding flocks, with reductions in the levels of green food and wheat by-products, have lowered their natural tocopherol contents. Singsen, Potter, Matterson, Bunnell \& Kozeff (1955) emphasize that it was with chicks hatched with depleted reserves that they were able to induce encephalomalacia by the addition of unsaturated fat. It has also been pointed out by Mokadi \& Budowski ( 1963 ) that the field outbreaks of encephalomalacia have not been confined to flocks for which added fat was used, nor has the replacement of cod-liver oil by stabilized vitamin A and D supplements entirely prevented the trouble. Though the presence of polyunsaturated or oxidized fat in the diets may be a major factor in precipitating the disease, it would be misleading to think of it as the only one. 


\section{REFERENCES}

Andrews, J. S., Mead, J. F. \& Griffith, W. H. (1960). F. Nutr. 7o, I 99.

Blaxter, K. L., Wood, W. A. \& McDonald, A. M. (i953). Br. F. Nutr. 7, 34.

Carpenter, K. J., Lea, C. H. \& Parr, L. J. (1963). Br. F. Nutr. 17, I5I.

Clement, G. H. (1966). Proc. Nutr. Soc. 25, 3 I.

Crampton, E. W., Common, R. H., Farmer, F. A., Wells, A. F. \& Crawford, D. (1953). F. Nutr. 49, 333.

Dam, H. (1943). Proc. Soc, exp. Biol. Med. 52, 285.

Degkwitz, E. \& Lang, K. (1962). Klin. Wschr. 40, 515.

Dow, C., Lawson, G. H. K., McFerran, J. B. \& Todd, R. J. (1963). Vet. Rec. 75, 76.

Grant, C. A. (1966). Proc. Nutr. Soc. 25, 18.

Gray, R. E. \& Robinson, H. E. (r94r). Poult. Sci. 20, $3^{6 .}$

Greenberg, S. M. \& Frazer, A. C. (1953). F. Nutr. 50, $42 \mathrm{I}$.

Kaunitz, H. (1962). In Symposium on Foods: Lipids and their Oxidation, p. 269. [H. W. Schultz, E. A. Day and R. O. Sinnhuber, editors.] Westport, Conn.: Avi Publishing Co. Inc.

Kaunitz, H., Johnson, R. E. \& Slanetz, C. A. (1952). F. Nutr. 46, 15 I.

Kreier, J. P., Elwood, F. R. \& Norton, H. W. (1961). Am. F. vet. Res. 22, 795.

Laksesvela, B. (1961). Meldinger, SSF, January r96r, p. 7. Quoted in Nutr. Abstr. Rev. (1961), 31, 1434.

Lea, C. H., Parr, L. J., L'Estrange, J. L. \& Carpenter, K. J. (1964). Br. F. Nutr. 18, 369.

L'Estrange, J. L., Carpenter, K. J., Lea, C. H. \& Parr, L. J. (1965a). Proc. Nutr. Soc. 24, vii.

L'Estrange, J. L., Carpenter, K. J., Lea, C. H. \& Parr, L. J. (1965b). Proc. Nutr. Soc. 24, xxxiii.

Machlin, L. J. \& Gordon, R. S. (1960). Proc. Soc. exp. Biol. Med. 103, 659.

March, B. E., Biely, J., Claggett, F. E. \& Tarr, H. L. A. (1962). Poult. Sci. 4r, 873.

Mokadi, S. \& Budowski, P. (1963). Br. F. Nutr. 17, 347.

O'Brien, P. J. \& Frazer, A. C. (1966). Proc. Nutr. Soc. 25, 9.

Oldfield, J. E., Sinnhuber, R. O. \& Rasheed, A. A. (1963). F. Am. Oil Chem. Soc. 40, 357.

Sigma (1964). Tech. Bull. Sigma Chemical Co., St Louis, Mo., USA, no. 505.

Singsen, E. P., Potter, L. M., Matterson, L. D., Bunnell, R. H. \& Kozeff, A. (1955). Poult. Sci. 34, 1075.

Swahn, O. \& Thafvelin, B. (1962). Vitams Horm. 20, 645 .

\section{$3 \dddot{f u l y}$, Second Session}

\section{Animal Nutrition, Second Part}

Chairman: Professor F. G. Young, DSc, PhD, FRS, Biochemical Laboratory, University of Cambridge

\section{The survival of vitamins in feeds containing unsaturated fats}

\section{By G. H. Clement, Roche Products Ltd, I 5 Manchester Square, London, $W_{\mathrm{I}}$}

The practice of adding fats to compound animal feeding-stuffs has not yet become established in this country, although investigations (particularly in Northern Ireland) into its possibilities have been proceeding for some time past. In America, however, where tallow and other fats are easy to obtain, large numbers of experiments have demonstrated that the addition of fat to high-energy rations not only improves the appearance and other physical characteristics of the rations, but also shows economically attractive increases in the weight of livestock feeding on them. The results obtained, however, may not be so advantageous in this country, where the consumer prefers meat and bacon to be much less fat than American tastes demand; added fat in the rations of fattening stock may produce carcasses which are too fat for 